\title{
モノサルフェートの前処理乾燥および共存物質の種類が エトリンガイト生成に及ぼす影響
}

\author{
品川英斗 ${ }^{* 1}$ 佐藤賢之介 ${ }^{* 2}$ 斎藤豪 ${ }^{* 3}$ 佐伯竜彦 ${ }^{* 3}$
}
*1 新潟大学 大学院自然科学研究科環境科学専攻 ( T950-2181 新潟県新潟市西区五十嵐二の町 8050)
*2 新潟大学 大学院自然研究科環境科学専攻 - 日本学術振興会特別研究員 DC ( T 950-2181 新潟県新潟市西区 五十嵐二の町 8050)
*3 新潟大学 工学部建設学科( T950-2181 新潟県新潟市西区五十嵐二の町 8050)

\begin{abstract}
要旨：本研究はモノサルフェートに対して、共存物質の種類および前処理乾燥の違いがエトリンガイトの 生成に及ぼす影響を実験的に把握することを目的とした。その結果、モノサルフェートと C-S-H を共存 させ、 $\mathrm{Na}_{2} \mathrm{SO}_{4}$ 水溶液を用いて練り混ぜ水和させた場合、エトリンガイト生成量が増加し、特に高 $\mathrm{C} / \mathrm{S}$ 比 の C-S-H を共存させた配合において生成量が大幅に増加することが実験的に示された。また、モノサル フェートや共存物質の C-S-H の前処理乾燥を強くし、 $\mathrm{Na}_{2} \mathrm{SO}_{4}$ 水溶液を用いて水和させた場合には、工 トリンガイト生成量が更に増加することが初めて実験的に示され、強い乾燥を受けた高 C/S 比の C-S-H の共存は、硫酸塩劣化による膨張性状に影響を及ぼす可能性が示唆された。
\end{abstract}

キーワード：エトリンガイト、モノサルフェート、C $-\mathrm{S}-\mathrm{H} 、 \mathrm{C} / \mathrm{S}$ 比、前処理乾燥、共存物質、液相 $\mathrm{pH}$ 、 液相 $\mathrm{Ca}^{2+}$ 濃度

\section{1. はじめに}

近年硫酸塩によるコンクリートの膨張劣化が国内外で問 題となって扔り、その主要因としてエトリンガイトの遅延 生成が挙げられている1, 2)。通常のセメント水和において 生成されたエトリンガイト $\left(3 \mathrm{CaO} \cdot \mathrm{Al}_{2} \mathrm{O}_{3} \cdot 3 \mathrm{CaSO}_{4} \cdot 32 \mathrm{H}_{2} \mathrm{O}\right)$ は、液相の硫酸イオン濃度の低下とともにモノサルフェー 卜 $\left(3 \mathrm{CaO} \cdot \mathrm{Al}_{2} \mathrm{O}_{3} \cdot \mathrm{CaSO}_{4} \cdot 12 \mathrm{H}_{2} \mathrm{O}\right)$ 一と転化する。海水や土 壤由来の外来硫酸塩により硫酸イオンが供給された場合、 モノサルフェートが硫酸イオンと反応し、再びエトリンガ イトが生成する。この遅れて再生成したエトリンガイトは 周囲の物質を押しのけて成長することで、コンクリートの ひび割れや膨張を引き起こしているものと考えられてい る。しかしながら、エトリンガイトの生成とセメント系硬 化体の膨張量との関倸については未解明な点が多い。

その一方で、Taylor ら ${ }^{3)}$ は周囲に存在する C-S-H な どの共存水和物の性質がエトリンガイトの膨張性状に密 接に関連していると指摘している。また、Kunther ら は、混和材を含むセメント系硬化体を硫酸塩に浸漬した 場合の膨張量に $\mathrm{C}-\mathrm{S}-\mathrm{H}$ の $\mathrm{CaO} / \mathrm{SiO}_{2}$ モル比 (以下 $\mathrm{C} / \mathrm{S}$ 比) が及ぼす影響について検討した結果、C-S-H の C/S 比 が低くなり液相への Ca 溶脱量が減少すると細孔溶液中 のエトリンガイトの過飽和度が減少し、膨張が抑制され ると報告している。

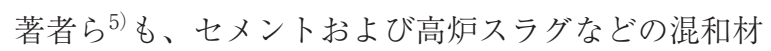
を用いたセメント系硬化体を硫酸塩溶液に浸漬して検討 した結果、セメント由来のエトリンガイト増加量と脵張 量に一定の関係があることが示された。セメント由来の
$\mathrm{C} / \mathrm{S}$ 比の高い $\mathrm{C}-\mathrm{S}-\mathrm{H}$ と、混和材由来の $\mathrm{C} / \mathrm{S}$ 比の低い C-S-H が共存している場合とでは、膨張性状が異なっ たことから、共存する水和物の性質がエトリンガイトの 生成量や膨張性状に影響するものと考えられる。しかし ながら、セメント系硬化体は他の水和物を多く含む複雑 な系であることから、エトリンガイトの生成に及ぼす C-S-H のみの影響を把握することは困難である。

それに加えて C-S-H は、乾燥条件によって構造が変 化する場合や、構造が変化しない場合でも密度や比表面 積が変化することが報告されている6)。また、モノサル フェートについても Baquerizo ら ${ }^{7)}$ の検討結果より、モ ノサルフェートの乾燥条件が異なると、結合水量が 12 から 10.5 に変化することで結晶構造が変化すると報告 されて扔り、水分状態の違いが物理的性質の違いとなっ てエトリンガイト生成に影響を及ぼすことも想定される。 そこで本研究では、エトリンガイト生成に、モノサル フェートの前処理乾燥の違い、扩よび共存物質の違いが それぞれどのような影響を及ぼすかを実験的に把握する ことを目的として、合成水和物を使用した単純な系を 用いて検討を行った。具体的にはモノサルフェートと C-S-H などの共存物質を合成し、異なる条件で乾燥さ せた後、それらを混合して硫酸ナトリウム水溶液を用い て練り混ぜ水和を行い、生成物を分析した。

\section{2. 実験概要}

2.1 モノサルフェートおよび共存物質の作製 モノサルフェート(略記 $\mathrm{Ms}$ ) は $\mathrm{C}_{3} \mathrm{~A}$ を用いて作製し 


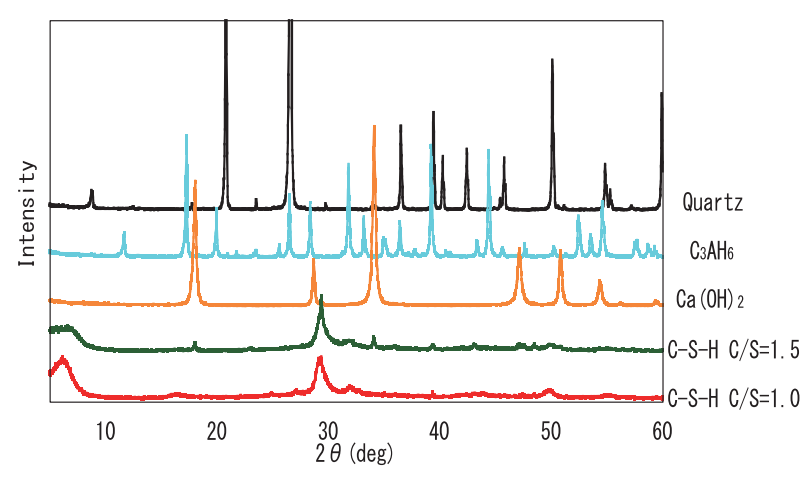

Fig. 1 XRD patterns of coexisting substance dried at RH $66 \%$

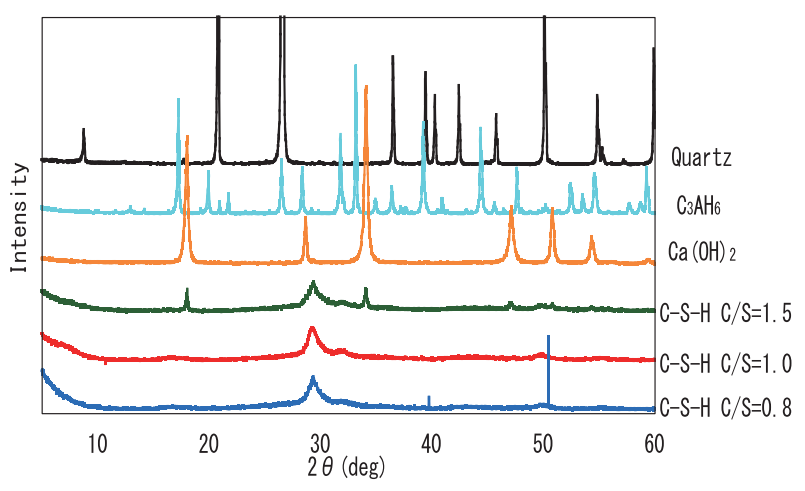

Fig. 2 XRD patterns of coexisting substance dried at $110{ }^{\circ} \mathrm{C}$
た。 $\mathrm{C}_{3} \mathrm{~A}$ は著者らの既報 ${ }^{8)}$ と同様に炭酸カルシウムと酸 化アルミニウムを所定のモル比となるよう秤量し、エ夕 ノールを用いて湿式混合した後、 $1,000{ }^{\circ} \mathrm{Cで}$ 仮焼し、成 型圧縮を行い $1,400{ }^{\circ} \mathrm{Cで} 3$ 時間焼成した。その後、粉 砕混合を行い、再び電気炉にて焼成した。この操作を 2 回操り返し合成した。得られた $\mathrm{C}_{3} \mathrm{~A}$ は、ボールミル にてブレーン值を $4,000 \mathrm{~cm}^{2} / \mathrm{g}$ 程度に調整した。モノサ ルフェートの作製は、 $\mathrm{C}_{3} \mathrm{~A}$ と二水石膏をそれぞれモル 比 1:1 で混合し、水結合材比 10 でイオン交換水を用 いてプラスチック容器内で水和させた。容器に窒素を封 入し $20{ }^{\circ} \mathrm{C}$ の恒温室内で 14 日間反応させた後、固相と 液相を吸引ろ過により分離した。

共存物質については $\mathrm{C} / \mathrm{S}$ 比 $=0.8 、 1.0$ および 1.5 の $\mathrm{C}-\mathrm{S}-\mathrm{H}$ 、ハイドロガーネット $\left(\mathrm{C}_{3} \mathrm{AH}_{6}\right)$ 、珪石微粉 末(Quartz)、水酸化カルシウム $\left(\mathrm{Ca}(\mathrm{OH})_{2}\right)$ を用いた。 C-S-H はゾルゲル法 ${ }^{9)}$ を用いて純薬合成した。水酸化 カルシウム飽和溶液とケイ酸エチルを目標 $\mathrm{C} / \mathrm{S}$ 比 $=$ 0.8、1.0 および 1.5 となるように混合し窒素雲囲気下 で $40{ }^{\circ} \mathrm{C}$ の恒温室内にて 48 時間反応させた。合成した $\mathrm{C}-\mathrm{S}-\mathrm{H}$ の固相と液相は、吸引ろ過によって分離した。 ハイドロガーネットは、上記のように作製した $\mathrm{C}_{3} \mathrm{~A}$ と イオン交換水を水結合材比 1 で練り混ぜ、窒素を封入 し $40{ }^{\circ} \mathrm{C}$ の恒温室内にて 28 日間反応させた後、固相と 液相を吸引ろ過により分離した。珪石微粉末、水酸化力 ルシウムについては市販品を用いた。なお、珪石微粉末 は硫酸ナトリウムと反応を示さないため、他の共存物質 の比較対象とした。

作製したモノサルフェートおよび上記共存物質は、 RH66 \%に調湿したデシケータ内および $110{ }^{\circ} \mathrm{C}$ 乾燥炉で 恒量となるまで乾燥させ、ボールミルを用いて $90 \mu \mathrm{m}$ 以下に粉砕した。なお、乾燥条件については、前述の Baquerizo $ら^{7)}$ の検討結果によると、モノサルフェート は RH27\%～97\%の範囲で乾燥させると、通常の結合 水量であり、RH8\%よりも低い乾燥条件で乾燥させる と結合水量が変化し XRD のピークがシフトすると報 告している。以上のことから、結晶構造に影響を及ほ さない通常の湿度条件として RH66\%を選定し、湿度
の低い条件として $110{ }^{\circ} \mathrm{C}$ 乾燥条件を選定した。また、 モノサルフェートはろ過直後に $50{ }^{\circ} \mathrm{C}$ で前処理乾燥を行 い、XRD/Rietveld 解析を用いて水和物の定量を行った。 Fig. 1 に RH66 \%で乾燥を行った上記共存物質の $2 \theta=$ $5^{\circ}$ 60の XRD パターンを示す。また Fig. 2 に $110{ }^{\circ} \mathrm{C}$ 乾燥を行った共存物質の XRD パターンを示す。

\section{2 硫酸ナトリウム水溶液による練り混ぜ水和}

Table 1 に硫酸ナトリウム水溶液水和試料の配合を示 す。上記のように作製したモノサルフェート単体およ びモノサルフェートに共存物質を質量比 $1: 1$ で混合し た各配合について、粉体：溶液 $=1: 2$ (質量比)として $0.5 \mathrm{~mol} / \mathrm{L}$ 硫酸ナトリウム水溶液を用いて練り混ぜ水和 を行い、スチロール瓶に打設した。その後 $20^{\circ} \mathrm{C}$ 環境下 で 1 日養生し、アセトンにより水和停止を行った。水 和停止後、減圧環境下でアセトンを乾燥させ、ボールミ ルを用いて試料を $90 \mu \mathrm{m}$ 以下に粉砕し、RH11 \%に調湿 したデシケータ内で恒量となり次第分析に用いた。

\section{3 生成水和物の定量}

水和前 (RH66\%乾燥と $110{ }^{\circ} \mathrm{C}$ 乾燥) のモノサルフェー トおよび硫酸ナトリウム練り混ぜ水和後の試料につい て、XRD/Rietveld 解析により水和物の定量を行い、エ トリンガイト生成量を比較した。XRDの条件は、ター ゲット $\mathrm{Cu}-\mathrm{K} \alpha$ 、管電流 $30 \mathrm{~mA}$ 、管電圧 $40 \mathrm{kV}$ 、走査範 囲 $2 \theta=5^{\circ} \sim 70^{\circ}$ 、ステップ幅 $0.02^{\circ}$ 、スキャンスピード $0.4^{\circ}$ min とし、Rietveld 解析ソフトは Topas4.2(Bruker AXS）を使用した。また、内部標準物質を添加し、非晶 質量の定量を行った。内部標準物質には、特級試薬の $\alpha-\mathrm{Al}_{2} \mathrm{O}_{3}$ を試料質量に対し内割りで $10 \%$ 混合した。非 晶質は式[1]を用いて定量し、この值から試料中のエト リンガイト生成量を算出した。

$$
\begin{aligned}
& G=\frac{100(A-R)}{A} \cdot \frac{100}{100-R} \\
& \text { ここに、 } G: \text { 非晶質量 }(\%) \\
& R: \alpha-\mathrm{Al}_{2} \mathrm{O}_{3} \text { の添加量 }(\%) \\
& A: \alpha-\mathrm{Al}_{2} \mathrm{O}_{3} \text { の Rietveld 解析定量值 }(\%)
\end{aligned}
$$


Table 1 Compositions of sodium sulfate hydrated samples

\begin{tabular}{|c|c|c|c|c|}
\hline $\begin{array}{c}\text { Types of } \\
\text { coexisting } \\
\text { substance }\end{array}$ & $\begin{array}{c}\text { Amount of } \\
\text { monosulfate } \\
\text { (mass\% })\end{array}$ & $\begin{array}{c}\text { Amount of } \\
\text { coexisting } \\
\text { substance } \\
\text { (mass\%) }\end{array}$ & $\begin{array}{c}\text { RH66 \% } \\
\text { dry } \\
\text { - }\end{array}$ & $\begin{array}{c}110{ }^{\circ} \mathrm{C} \\
\text { dry }\end{array}$ \\
\hline Quartz & 50 & 50 & $\bigcirc$ & $\bigcirc$ \\
\hline $\mathrm{C}_{3} \mathrm{AH}_{6}$ & 50 & 50 & $\bigcirc$ & $\bigcirc$ \\
\hline $\mathrm{Ca}(\mathrm{OH})_{2}$ & 50 & 50 & $\bigcirc$ & $\bigcirc$ \\
\hline $\mathrm{C}-\mathrm{S}-\mathrm{H} \mathrm{C} / \mathrm{S}=1.5$ & 50 & 50 & $\bigcirc$ & $\bigcirc$ \\
\hline $\mathrm{C}-\mathrm{S}-\mathrm{H} \mathrm{C} / \mathrm{S}=1.0$ & 50 & 50 & $\bigcirc$ & $\bigcirc$ \\
\hline $\mathrm{C}-\mathrm{S}-\mathrm{H} \mathrm{C} / \mathrm{S}=0.8$ & 50 & 50 & - & $\bigcirc$ \\
\hline
\end{tabular}

\section{4 エトリンガイト生成時における発熱速度の測定}

反応初期のエトリンガイト生成時における発熱速度を 測定するために、熱量計を用いて発熱量を測定した。な お、測定は初期の水和発熱の分析に特化した反応速度 測定装置(東京理工製 IC-20) ${ }^{10)}$ を用いて行った。配合に ついては $110{ }^{\circ} \mathrm{C}$ 乾燥のモノサルフェート単体、モノサ ルフェートと珪石微粉末を共存させた配合、モノサル フェートと $\mathrm{C}-\mathrm{S}-\mathrm{H}(\mathrm{C} / \mathrm{S}$ 比=1.0、1.5) を共存させた配 合の計 4 種類で行った。なお、測定は、各配合の粉体 $1.5 \mathrm{~g}$ に対して $0.5 \mathrm{~mol} / \mathrm{L}$ 硫酸ナトリウム水溶液を $4.5 \mathrm{~mL}$ 注 入し、2 分間攪找した。発熱量の測定は注水後から 60 分後まで行った。

\section{5 液相の $\mathrm{pH}$ およびイオン組成の定量}

水和試料における液相の $\mathrm{pH}$ およびイオン組成を評 価するために、 $110{ }^{\circ} \mathrm{C}$ 乾燥の各配合について粉体：溶液 $=1: 3$ (質量比)として $0.5 \mathrm{~mol} / \mathrm{L}$ 硫酸ナトリウム水溶液 を用いて練り混ぜ水和を行い、スチロール瓶に打設し、 $20{ }^{\circ} \mathrm{C}$ 環境下で 1 日養生した。水和後の試料は遠心分離 機を用いて液相を分離し、測定用試料とした。液相の $\mathrm{pH}$ はガラス電極式 $\mathrm{pH}$ メーターを用いて測定し、液相 のイオン組成についてはイオンクロマトグラフを用いて $\mathrm{Na}^{+} 、 \mathrm{Ca}^{2+}$ および $\mathrm{SO}_{4}{ }^{2-}$ を定量した。

\section{3. 実験結果}

\section{1 前処理乾燥によるモノサルフェートの変化がエト}

\section{リンガイト生成に及ぼす影響}

Fig. 3 に RH66\%および $110{ }^{\circ} \mathrm{C} 、 50{ }^{\circ} \mathrm{C}$ で前処理乾燥 を行ったモノサルフェートの $2 \theta=5^{\circ} \sim 25^{\circ}$ の XRD パター ンを示す。 $110{ }^{\circ} \mathrm{C}$ 乾燥の場合では、モノサルフェートの みのピークが確認されたが、RH66 \% 乾燥の場合では、 モノサルフェートのピークと共にエトリンガイトのピー クが確認された。

エトリンガイトは $110{ }^{\circ} \mathrm{C}$ 程度の高温で乾燥させた場合、 脱水によってメタエトリンガイトへ転化し、XRD にお いて非晶質化することが報告されており11)、本研究にお いても、110 ${ }^{\circ} \mathrm{Cで}$ 乾燥させた試料において非晶質化した エトリンガイトが含まれる可能性が考えられた。しかし、

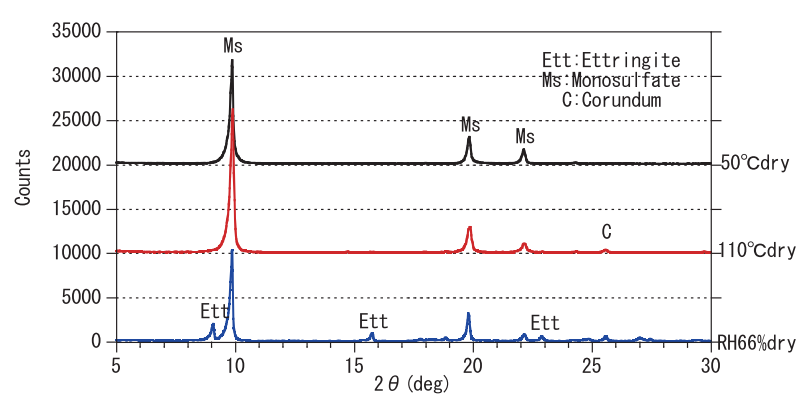

Fig. 3 XRD patterns of monosulfate before sodium sulfate hydration

Taylor ら ${ }^{12)}$ は、 $50{ }^{\circ} \mathrm{C}$ 程度で乾燥した場合はエトリンガ イトの結合水量がほとんど変化しないと報告しており、 非晶質化は生じていないものと考えられる。以上のこと から、50 ${ }^{\circ} \mathrm{C}$ 乾燥した試料においてエトリンガイトのピー クが確認されなければ、 $110{ }^{\circ} \mathrm{C} て ゙$ 前処理乾燥を行ったモ ノサルフェートには、非晶質化したエトリンガイトは含 まれていないと考えられるが、Fig. 3 に示した $50{ }^{\circ} \mathrm{C}$ 乾 燥の試料においてもエトリンガイトのピークが確認され なかった。したがって、RH66％で乾燥させることでエ トリンガイトが少量生成されたものと推察される。

Fig. 4 に、Fig. 3 に示した RH66 \%および $110{ }^{\circ} \mathrm{C} て ゙$ 前 処理乾燥を行ったモノサルフェートの XRD パターン を重ねた結果を示す。前述の通り Baquerizo ら ${ }^{7)}$ は、モ ノサルフェートの乾燥条件が RH8 \%の場合、XRDの モノサルフェートのピークが通常の位置である $10^{\circ}$ か ら $11^{\circ}$ にシフトすると報告している。1 $10^{\circ}$ や $20^{\circ}$ 付近のモ ノサルフェートのピークに着目すると、 $110{ }^{\circ} \mathrm{C}$ 乾燥の場 合、RH66\%と比較して顕著なピークシフトは確認され なかったが、僅かに広角側に広がったことが確認された。 なお、XRD では装置等によっては測定時のピークがず れることも想定され、Fig. 4 におけるピークの僅かなず れが装置等の測定時のずれでないことを確かめるため に、25.5付近の corundum のピークに着目すると、ピー クのずれは確認されなかった。したがって、Fig. 4 にお ける僅かなピークのずれは装置のずれではないと言え る。また、Rietveld 解析より測定した両乾燥条件のモノ サルフェート格子定数の值を Table 2 に示す。RH66％ に比べて $110{ }^{\circ} \mathrm{C}$ 乾燥の試料において、顕著な差は確認 されなかったものの、c 軸方向の值が僅かであるが小さ い值をとった。したがって、本研究においても、前処理 乾燥によってモノサルフェートの結晶構造が変化したも のと推察される。

続いて Fig. 5 に RH66 \%および 110 ○で乾燥したモ ノサルフェートを硫酸ナトリウムで練り混ぜ水和させ た後の $2 \theta=5^{\circ} \sim 25^{\circ}$ の XRD パターンを示す。RH66\% 乾燥の場合、水和前後でエトリンガイトのピークにほと んど変化は見られず、モノサルフェートのピーク低下も 生じなかったのに対し、110 ${ }^{\circ} \mathrm{C}$ 乾燥の場合ではモノサル フェートのピークが低下し、エトリンガイトのピークが 


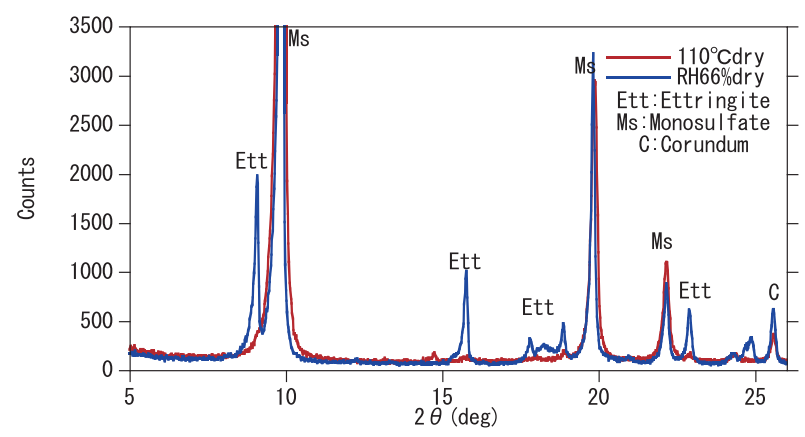

Fig. 4 XRD patterns of monosulfate before sodium sulfate hydration

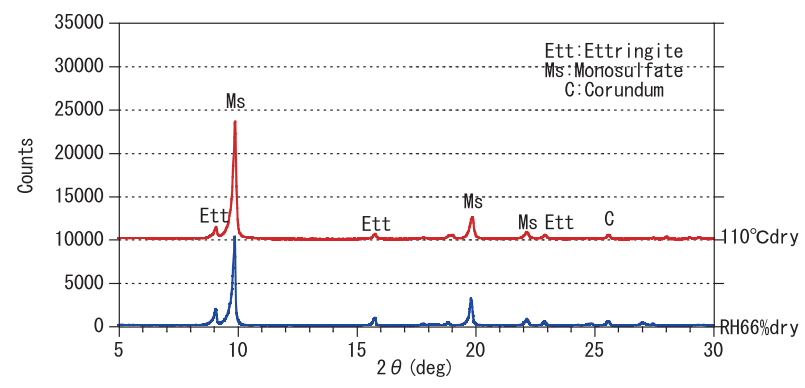

Fig. 5 XRD patterns of monosulfate after sodium sulfate hydration

出現した。したがって、モノサルフェートの前処理乾燥 が異なる場合、エトリンガイト生成量が変化し、強い乾 燥を受けた場合には、エトリンガイト生成量が増大する 結果となった。

\section{2 共存物質がエトリンガイト生成に及ぼす影響}

Fig. 6 に RH66 \%で乾燥させたモノサルフェートおよ び共存物質を混合し、硫酸ナトリウム水溶液で練り混 ぜ水和させた試料の $2 \theta=5^{\circ} \sim 15^{\circ}$ の XRD パターンを示 す。珪石微粉末は硫酸ナトリウムと反応を示さないこ とから、珪石微粉末を共存させた場合の XRD パターン を基準として、他の共存物質の XRD パターンと比較を 行った。なお、前述の通り RH66 \%で乾燥したモノサル フェートは、水和前後でエトリンガイトのピークに変化 は確認されなかったことから、Fig. 6 において珪石微粉 末共存の配合で確認できるエトリンガイトのピークも、 水和前から存在するものと考えられる。

ハイドロガーネット、水酸化カルシウムを共存させた 場合においては、珪石微粉末を共存させた場合と比較し て、エトリンガイトのピークは増大しなかった。ハイド ロガーネットおよび水酸化カルシウムが共存し、エトリ ンガイトの生成に必要なカルシウム源が存在している場 合でも、エトリンガイトの生成量にほとんど影響を及ぼ さない結果となった。その一方で、モノサルフェートに 各 C/S 比の C-S-H を共存させた配合では、モノサル フェートのピークが大幅に減少し、9付近のエトリンガ イトのピークが増大した。
Table 2 Refined lattice parameter of before sodium sulfate hydration

\begin{tabular}{|c|c|c|}
\hline \multirow{2}{*}{ drying condition } & \multicolumn{2}{|c|}{ lattice parameter } \\
\cline { 2 - 3 } & $\mathrm{a}(\AA)$ & $\mathrm{c}(\AA)$ \\
\hline $\mathrm{RH} 66 \%$ & 5.7641 & 26.8552 \\
\hline $110^{\circ} \mathrm{C}$ & 5.7612 & 26.7224 \\
\hline
\end{tabular}

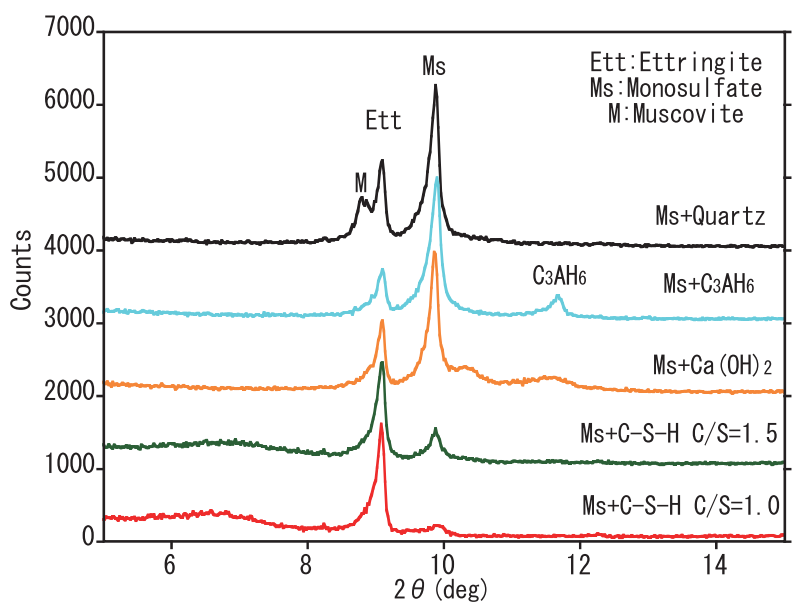

Fig. 6 XRD patterns of monosulfate + coexisting substance dried at $\mathrm{RH} 66 \%$ after sodium sulfate hydration

また、Fig. 7 に $110{ }^{\circ} \mathrm{C} て ゙$ 前処理乾燥を行ったモノサル フェートおよび共存物質を混合し、硫酸ナトリウム水溶 液で水和させた試料の $2 \theta=5^{\circ} \sim 15^{\circ}$ の XRD パターンを 示す。珪石微粉末を共存させた場合においては、 $110{ }^{\circ} \mathrm{C}$ 乾燥のモノサルフェート単体の水和後と同様にエトリ ンガイトのピークが出現した。前処理乾燥に $110{ }^{\circ} \mathrm{C}$ 乾 燥を施した試料においても RH66 \% 乾燥の場合と同様、 ハイドロガーネット、水酸カルシウムを共存させた場合 においては、珪石微粉末を共存させた場合と比較してエ トリンガイトのピークはほとんど増大しなかった。一方 で、RH66 \%乾燥の場合と同様に、C-S-H を共存させた 配合においてエトリンガイトのピークが増大した。

したがって RH66 \%と $110{ }^{\circ} \mathrm{C}$ 乾燥の結果より、水酸 化カルシウムとハイドロガーネットを共存させた場合 においてはエトリンガイト生成にほとんど影響を及ぼ さないものと考えられる。また、モノサルフェートと C-S-H が共存した場合、乾燥条件に関係なく、他の共 存物質と比較してエトリンガイトの生成が大幅に促進さ れることが示された。

続いて水和後に生成したエトリンガイト量について比 較するために、Rietveld 解析結果によって定量したモ ノサルフェートに共存物質を混和した配合のエトリンガ イト生成量を Fig. 8 に示す。なお、RH66 \%乾燥のエト リンガイト量は、水和後の生成量から水和前の生成量を 差し引いた值である。まず、共存物質の影響に着目する と、他の共存物質と比較して、C-S-H を共存させた場 


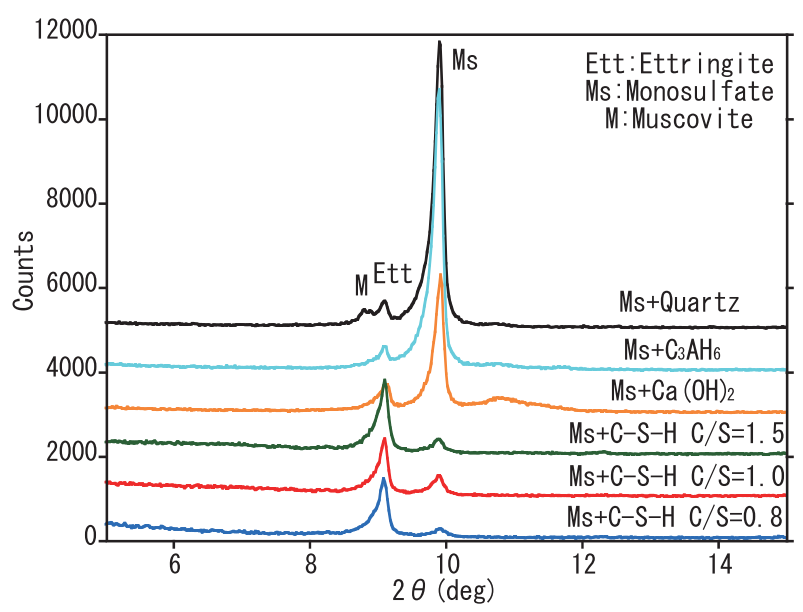

Fig. 7 XRD patterns of monosulfate + coexisting substance dried at $110{ }^{\circ} \mathrm{C}$ after sodium sulfate hydration

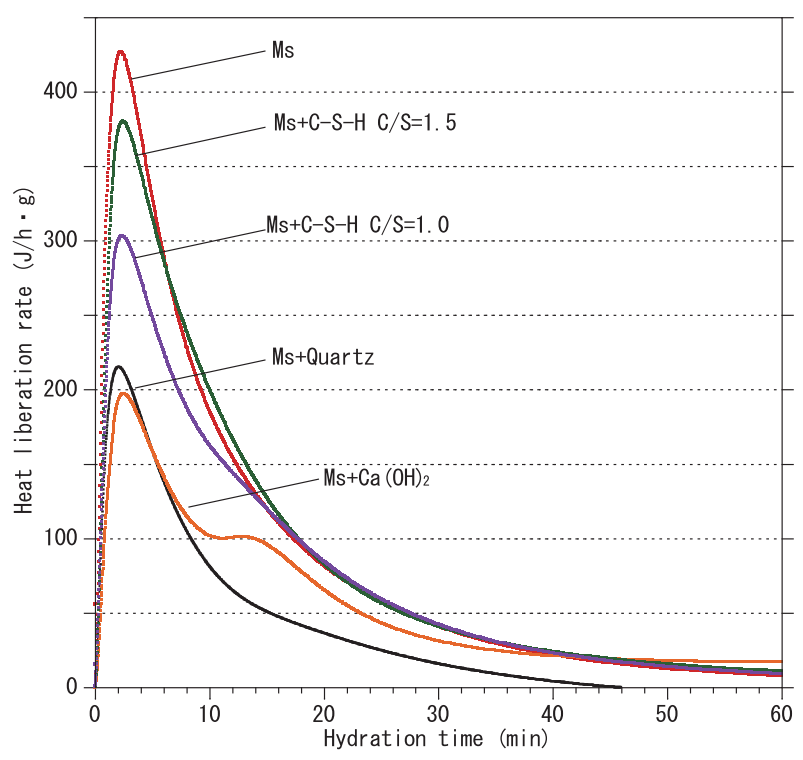

Fig. 9 Heat liberation rate during formation of ettringite

合において、両乾燥条件でエトリンガイト生成量が顕著 に増大する結果となった。また、 $\mathrm{C} / \mathrm{S}$ 比 $=1.0$ と C/S 比 $=1.5$ の C-S-H の共存させた場合の結果に着目する と、2つの乾燥条件においてともに、 C/S 比 $=1.0$ に比 ベて、 $\mathrm{C} / \mathrm{S}$ 比 $=1.5$ を共存させた場合にエトリンガイト 生成量が多くなった。したがって、C/S 比 $=1.5$ 程度の $\mathrm{C} / \mathrm{S}$ 比が高い $\mathrm{C}-\mathrm{S}-\mathrm{H}$ を共存させた場合は、エトリン ガイト生成が促進されることが明らかとなり、Taylor、 Famy らによる提言 ${ }^{3)}$ が初めて実験によって示されたと 言える。

また、Fig. 8 における RH66 \%乾燥と $110{ }^{\circ} \mathrm{C}$ 乾燥の結 果を比較すると、すべての共存物質において RH66 \% 乾 燥に比べて、110 ${ }^{\circ} \mathrm{C}$ 乾燥の場合においてエトリンガイト 生成量が増大した。さらに、C/S 比 $=1.5$ と $\mathrm{C} / \mathrm{S}$ 比 $=1.0$ の $\mathrm{C}-\mathrm{S}-\mathrm{H}$ を共存させた場合のエトリンガイト生成量の 差 (図中矢印)に着目すると、RH66 \%乾燥の場合よりも

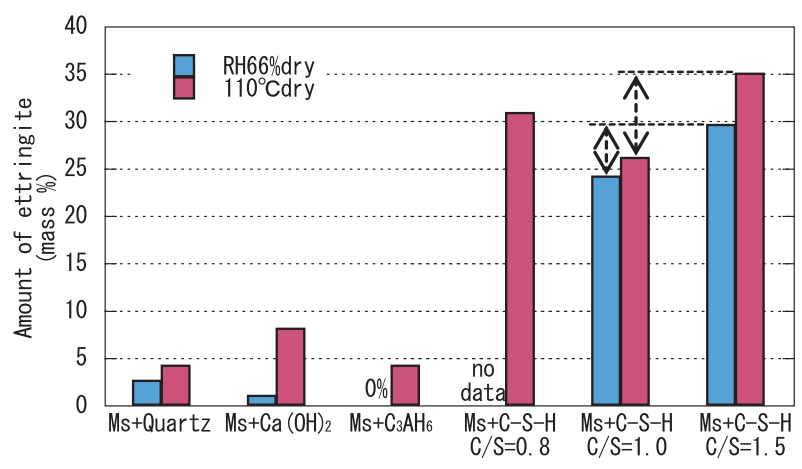

Fig. 8 Ettringite amount of monosulfate + coexisting substance after sodium sulfate hydration

$110{ }^{\circ} \mathrm{C}$ 乾燥の場合において、生成量の差が大きくなった。 したがって試料の乾燥が強いほど、共存する C-S-H の $\mathrm{C} / \mathrm{S}$ 比がエトリンガイト生成に及ぼす影響が大きくな ることが示唆された。

次に本実験で行った 1 日養生の条件下において、硫 酸ナトリウム水溶液を用いた水和後に、試料が十分に平 衡状態に達しているかについて確認するため、3 点式羽 根つき熱量計を用いて発熱速度の測定を行った。Fig. 9 に練り混ぜ開始から 60 分後までの発熱速度の結果を示 す。モノサルフェート単体、モノサルフェートに共存物 質を混合させた試料の両配合において、練り混ぜ直後 にエトリンガイト生成に起因する発熱ピークが確認さ れ、60 分後までには殆ど発熱ピークが収束した。した がって硫酸ナトリウム水溶液を用いた練り混ぜ水和から 1 日経過後においては、十分に反応が進行し平衡状態に 達していると考えられる。

また、モノサルフェート単体の配合において発熱ピー クが最も大きな值をとり、モノサルフェート量が半分の 共存物質を混合させた配合では、珪石微粉末、水酸化 カルシウムを共存させた場合においてはほぼ同等の值 を示し、C-S-H を共存させた場合において大きな值を とった。さらに、 $\mathrm{C} / \mathrm{S}$ 比 $=1.0$ よりも $\mathrm{C} / \mathrm{S}$ 比 $=1.5$ の C-S-H を共存させた場合において発熱量が大きくなっ た。以上のように、発熱速度の結果においても、Fig. 8 に示した Rietveld 定量值の結果と同じ傾向を示した。

\section{3 液相の $\mathrm{pH}$ および Ca 溶脱量についての比較}

Table 3 に $110{ }^{\circ} \mathrm{C}$ で乾燥させたモノサルフェートおよ び共存物質を混合し、硫酸ナトリウム水溶液で練り混ぜ 水和させ、1 日養生を行った試料の液相の $\mathrm{pH}$ とイオン 濃度の測定值を示す。なお、3.2 節でも述べたように、 練り混ぜ水和から 60 分後には反応が収束していること から、1 日後には平衡状態に達していると考えられる。

まず、 $\mathrm{pH}$ の值に着目すると、pH11.57〜 13.29 と すべての試料でエトリンガイトの安定生成域とされる pH9.0 13.4の值を取り ${ }^{13)}$ 、水酸化カルシウムを共存 させた配合において、最も高い $\mathrm{pH}$ の值を示す結果と なった。水酸化カルシウム共存においては、硫酸ナト リウム水溶液を用いた水和後に、水酸化カルシウムの 
Table $3 \mathrm{pH}$ and ion composition of liquid phase

\begin{tabular}{|c|c|c|c|c|c|}
\hline & $\begin{array}{c}\text { Drying } \\
\text { condition }\end{array}$ & $\mathrm{pH}$ & $\begin{array}{c}\mathrm{Na}^{+} \\
\mathrm{mol} / \mathrm{L}\end{array}$ & $\begin{array}{l}\mathrm{Ca}^{2+} \\
\mathrm{mol} / \mathrm{L}\end{array}$ & $\begin{array}{l}\mathrm{SO}_{4}{ }^{2-} \\
\mathrm{mol} / \mathrm{L}\end{array}$ \\
\hline Monosulfate & \multirow{7}{*}{$110^{\circ} \mathrm{C}$} & 12.38 & 1.81 & 0.01 & 0.35 \\
\hline Ms + Quartz & & 12.54 & 1.13 & 0.02 & 0.38 \\
\hline $\mathrm{Ms}+\mathrm{C}_{3} \mathrm{AH}_{6}$ & & 12.43 & 1.11 & - & 0.34 \\
\hline $\mathrm{Ms}+\mathrm{Ca}(\mathrm{OH})_{2}$ & & 13.39 & 1.09 & 0.04 & 0.05 \\
\hline $\begin{array}{c}\mathrm{Ms}+\mathrm{C}-\mathrm{S}-\mathrm{H} \\
\mathrm{C} / \mathrm{S}=0.8\end{array}$ & & 11.68 & 0.78 & 0.04 & 0.24 \\
\hline $\begin{array}{c}\mathrm{Ms}+\mathrm{C}-\mathrm{S}-\mathrm{H} \\
\mathrm{C} / \mathrm{S}=1.0\end{array}$ & & 12.60 & 0.88 & 0.06 & 0.28 \\
\hline $\begin{array}{c}\mathrm{Ms}+\mathrm{C}-\mathrm{S}-\mathrm{H} \\
\mathrm{C} / \mathrm{S}=1.5\end{array}$ & & 11.57 & 0.86 & 0.12 & 0.13 \\
\hline
\end{tabular}

$\mathrm{Ca}^{2+}$ と $\mathrm{OH}^{-}$が解離することで液相中の $\mathrm{OH}^{-}$濃度が増 加し、 $\mathrm{pH}$ が上昇したものと考えられる。

続いて $\mathrm{Na}^{+}$濃度に着目すると、モノサルフェート単 体では、1.81mol/L と最も高い值をとり、モノサルフェー 卜量が半分である珪石微粉末を共存させた場合において も、1.13mol/L と高い值をとった。 $\mathrm{Na}^{+}$濃度の測定につ いて液相の $\mathrm{Na}^{+}$濃度が高く、検量線を外挿して值を算 出したことから、実際の值よりも大きな值を示した可能 性が考えられた。したがって $\mathrm{Na}^{+}$濃度の測定について は、今後検討が必要であると考えられる。

また、 $\mathrm{Ca}^{2+}$ 濃度に着目すると $\mathrm{C} / \mathrm{S}$ 比 $=1.5$ 共存の 場合において最も高い值となったが、他の $\mathrm{C} / \mathrm{S}$ 比の C-S-H 共存や水酸化カルシウム共存の場合では、配合 間でほとんど同程度の值となった。特に水酸化カルシウ ム共存と $\mathrm{C} / \mathrm{S}$ 比 $=0.8$ の $\mathrm{C}-\mathrm{S}-\mathrm{H}$ 共存の場合では $\mathrm{Ca}^{2+}$ 濃度が同じ值をとった。

\section{4. エトリンガイト生成に関する考察}

以上の結果を踏まえてモノサルフェートの前処理乾燥 の違いや、共存物質の種類および液相のカルシウム溶脱 量や $\mathrm{pH}$ がエトリンガイト生成に及ぼす影響について考 察した。

まず、共存する $\mathrm{C}-\mathrm{S}-\mathrm{H}$ の $\mathrm{C} / \mathrm{S}$ 比の違いに着目する と、3.2 節でも述べたように $\mathrm{C} / \mathrm{S}$ 比の異なる $\mathrm{C}-\mathrm{S}-\mathrm{H}$ を 共存させた場合にエトリンガイト生成量が異なる結果が 示された。 $\mathrm{C}-\mathrm{S}-\mathrm{H}$ の $\mathrm{C} / \mathrm{S}$ 比が異なる場合、 $\mathrm{C}-\mathrm{S}-\mathrm{H}$ の 密度および比表面積が異なり ${ }^{6)}$ 、㓌イオンの吸着性も異 なる な $^{8)}$ 、物理的・化学的性質の違いがエトリンガイ 卜生成に影響を及ぼしているものと推察される。しか し、 $110{ }^{\circ} \mathrm{C}$ 乾燥においては、C $/ \mathrm{S}$ 比=1.0 の $\mathrm{C}-\mathrm{S}-\mathrm{H}$ を 共存させた場合よりも、 $\mathrm{C} / \mathrm{S}$ 比 $=0.8$ の $\mathrm{C}-\mathrm{S}-\mathrm{H}$ を共存 させた場合においてエトリンガイト生成量が多くなっ た。C-S-H の C/S 比とエトリンガイト生成量との関連 性については、今後さらなる検討が必要である。

次に試料の乾燥条件に着目すると、強い乾燥を施した 試料においてエトリンガイト生成量が増大し、C-S-H の $\mathrm{C} / \mathrm{S}$ 比の違いがエトリンガイト生成に及ぼす影響も
大きくなった。著者ら ${ }^{6)}$ はこれまでにモノサルフェート や C-S-H は乾燥条件によって密度や比表面積が変化す ることを明らかにしており、水分状態の違いが物理的性 質の違いとなってエトリンガイト生成に影響を及ぼして いると考えられる。

続いて液相の $\mathrm{pH}$ および $\mathrm{Ca}$ 溶脱量がエトリンガイ 卜生成に及ぼす影響について述べる。前述のように Kunther ら ${ }^{4)}$ は、共存する $\mathrm{C}-\mathrm{S}-\mathrm{H}$ の C/S 比が低くなり $\mathrm{Ca}$ 溶脱量が減少すると細孔溶液中のエトリンガイトの 過飽和度が減少し、膨張が抑制されると考察している。 即ち、液相の $\mathrm{Ca}^{2+}$ 濃度が高いほどエトリンガイトが生 成されやすいと考えられる。水酸化カルシウム共存と $\mathrm{C} / \mathrm{S}$ 比 $=0.8$ の $\mathrm{C}-\mathrm{S}-\mathrm{H}$ 共存の場合では、 $\mathrm{Ca}^{2+}$ 濃度が 同じ值をとり、 $\mathrm{pH}$ については、どちらの場合において もエトリンガイトの安定生成域をとったことから、C/S 比 $=0.8$ の C-S-H を共存させた場合と、水酸化カルシ ウムを共存させた場合においてはエトリンガイト生成 量が同等となると考えられたが、Fig. 8 の結果より C/S 比 $=0.8$ の C-S-H を共存させた場合においてエトリ ンガイト生成量が大幅に増大する結果となった。また、 Table 3 の $\mathrm{C} / \mathrm{S}$ 比 $=0.8$ と $\mathrm{C} / \mathrm{S}$ 比 $=1.0$ の $\mathrm{C}-\mathrm{S}-\mathrm{H}$ を共 存させた場合の結果に着目すると、 $\mathrm{Ca}^{2+}$ 濃度は $\mathrm{C} / \mathrm{S}$ 比 $=1.0$ の C-S-H を共存させた場合において高い值をと り、 $\mathrm{pH}$ はどちらもエトリンガイトの安定生成域をとっ たことから、C/S 比=1.0の C-S-H を共存させた場合 においてエトリンガイト生成量が増大すると予想された が、Fig. 8 の結果より C $/ \mathrm{S}=0.8$ の $\mathrm{C}-\mathrm{S}-\mathrm{H}$ を共存させ た配合においてエトリンガイト生成量が増大する結果と なった。

以上のように本研究の結果では、液相中の $\mathrm{Ca}^{2+}$ 濃度 が同等の場合においてもエトリンガイト生成量に大きな 違いが生じ、共存する $\mathrm{C}-\mathrm{S}-\mathrm{H}$ の $\mathrm{C} / \mathrm{S}$ 比が低く液相の $\mathrm{Ca}^{2+}$ 濃度がほぼ同程度の場合でも、エトリンガイト生 成量は大きく変化した。したがってエトリンガイト生成 には、液相の $\mathrm{pH}$ や $\mathrm{Ca}^{2+}$ 濃度よりも $\mathrm{C}-\mathrm{S}-\mathrm{H}$ 自体の特 性(例えば C-S-H の結晶あるいは凝集構造が有する幾 何学的特徵やそれに起因する水分の保有状態)、あるい は C-S-H の触媒としての作用が大きく影響している可 能性が考えられるが、詳細なメカニズムについては今後 検討が必要である。

\section{5. まとめ}

本研究は、モノサルフェートと共存物質の前処理乾燥 の違いおよび共存物質の種類がエトリンガイトの生成に 及ぼす影響を実験的に把握することを目的として検討を 行った。モノサルフェート単体およびモノサルフェート と共存物質を混合し硫酸ナトリウム水溶液を用いて練り 混ぜ水和を行い、水和後のエトリンガイト生成量の比較・ 検討を行った結果、以下のような結論を得た。

（1）モノサルフェートと C-S-H を共存させ、硫酸ナ トリウム水溶液を用いて練り混ぜ水和させた場合、 
エトリンガイト生成量が増加し、特に高 $\mathrm{C} / \mathrm{S}$ 比の C-S-H を共存させた配合において生成量が大幅に 増加することが、初めて実験的に示された。

（2）モノサルフェートや共存物質に強い前処理乾燥を与 え、硫酸ナトリウム水溶液を用いて練り混ぜ水和 させた場合に、エトリンガイト生成量が増加した。 これにより、強い乾燥を受けた高 $\mathrm{C} / \mathrm{S}$ 比の $\mathrm{C}-\mathrm{S}-\mathrm{H}$ が共存する場合、硫酸塩劣化による膨張性状に影響 を及ぼす可能性が示唆された。

（3）モノサルフェートおよび共存物質を硫酸ナトリウム 水溶液で練り混ぜ水和させた際の液相の $\mathrm{pH}$ とイ オン濃度を測定した結果、液相の $\mathrm{pH}$ および $\mathrm{Ca}^{2+}$ 濃度が同等の場合においてもエトリンガイト生成量 の変化が生じた。したがってエトリンガイト生成に は、液相の $\mathrm{pH}$ や $\mathrm{Ca}^{2+}$ 濃度ではなく $\mathrm{C}-\mathrm{S}-\mathrm{H}$ 自体 の特性、あるいは C-S-H の触媒としての作用が大 きく影響しているものと推察された。

\section{謝辞：}

本研究は科学研究費補助金(課題番号：16K06438)によ り行ったものであることを付記しここに謝意を表します。

\section{参考文献：}

1）土木学会：セメント系構築物と周辺地盤の化学的相 互作用研究小委員会 (345 委員会) 成果報告書及びシ ンポジウム講演概要集、pp. 246-261（2014）

2) M. D. Cohen et al. : Sulfate attack on concrete-reserch needs, ACIMaterials Jourrnal, No. 88, pp. 6269 (1991)

3) H. F. W. Taylor et al. : Delayed ettringite formation, Cement and Concrete Research, Vol. 31, Issue5, pp. 683-693 (2001)

4) Wolfgang Kunther et al. : Influence of the $\mathrm{Ca} / \mathrm{Si}$ ratio of the $\mathrm{C}-\mathrm{S}-\mathrm{H}$ phase on the interaction with sulfate ions and its impact on the ettringite crystallization pressure, Cement and Cncrete Researth, Vol. 69, pp. 37-49 (2015)

5）佐藤賢之介ほか：エトリンガイトの生成量および生 成起源が長期間硫酸塩に浸漬した高炉セメント系材 料の耐硫酸塩性に及ぼす影響、セメント・コンクリー 卜論文集、Vol. 68、pp. 396-403（2014）

6）須田裕哉ほか：セメント系硬化体の水和物の比表面 積に関する研究、セメント・コンクリート論文集、 No. 65、pp. 103-110 (2011)

7) Luis G Baquerizo et al. : Methods to determine hydration states of minerals and cement hydrates, Cement and Concrete Research, Vol. 65, pp. 85-95 (2014)

8）寺戸政成ほか：カルシウムアルミネート系水和物を 考慮したセメント系硬化体の比表面積推定方法に関 する基礎的研究、セメント・コンクリート論文集、 Vol. 66、pp. 197-204（2012）

9）中村明則ほか：ケイ酸カルシウム水和物による塩化 物イオン、硫酸イオンおよびリン酸イオンの吸着、 日本化学会誌、No. 6、pp. 415-420（1999）

10）一瀬龍太郎ほか：石灰石微粉末を置換したアルミ ネート高含入セメントの流動性、セメント・コンク リート論文集、No. 62、pp. 8-13（2008）

11) Q. Zhou, et et al. : Metaettringite, a decomposition product of ettringite, Cement and Concrete Research, Vol. 34, pp. 703-710 (2004)

12) H. F. W. Taylor : Cement Chemistry, 2nd Edition, Thomas Telford (1997)

13) Jachen Stark et al. : コンクリートの耐久性、セメ ント協会、第 2 版、p. 142 (2003) 


\title{
EFFECT OF PRETREATMENT DRYING OF MONOSULFATE AND COEXISTING HYDRATES ON ETTRINGITE FORMATION
}

\author{
Eito SHINAGAWA ${ }^{* 1}$, Kennosuke SATO*2, Tsuyoshi SAITO*3 and Tatsuhiko SAEKI*3 \\ *1 NIIGATA UNIVERSITY, Graduate School of Science and Technology (8050, Igarashi Ninocho, \\ Nishi-ku, Niigata-shi, Niigata 950-2181, Japan) \\ *2 NIIGATA UNIVERSITY, Graduate School of Science and Technology, JSPS Research Fellow \\ (8050, Igarashi Ninocho, Nishi-ku, Niigata-shi, Niigata 950-2181, Japan) \\ *3 NIIGATA UNIVERSITY, Department of Civil Engineering (8050, Igarashi Ninocho, Nishi-ku, \\ Niigata-shi, Niigata 950-2181, Japan)
}

\begin{abstract}
Sulfate attack is known as one of the deterioration phenomena of concrete structures. In particular, delayed ettringite formation is considered a serious problem. According to previous researches, it has been pointed out that delayed ettringite formation is affected by the hydrates coexisting around monosulfate, however it has not been shown experimentally yet. The purpose of this research is to discuss that the effect of pretreatment drying of monosulfate and coexisting substances on ettringite formation. As a result, when a mixture of monosulfate and $\mathrm{C}-\mathrm{S}-\mathrm{H}$ was mixed and hydrated using an aqueous solution of $\mathrm{Na}_{2} \mathrm{SO}_{4}$, the amount of ettringite was increased. In particular, it was shown experimentally that the amount ettringite was greatly increased when coexisting the $\mathrm{C}-\mathrm{S}-\mathrm{H}$ with high $\mathrm{C} / \mathrm{S}$ ratio. In addition, it has been shown for the first time that amount of the ettringite is further increased after hydration with an aqueous solution of $\mathrm{Na}_{2} \mathrm{SO}_{4}$ as a result of strongly pre-treatment drying of monosulfate and coexisting $\mathrm{C}-\mathrm{S}-\mathrm{H}$. Therefore, it maybe suggested that the expansion due to sulfate attack was affected by coexisting of strongly dried $\mathrm{C}-\mathrm{S}-\mathrm{H}$ with high $\mathrm{C} / \mathrm{S}$ ratio.
\end{abstract}

KEY WORDS : Ettringite, Monosulfate, C-S-H, C/S ratio, Pretreatment drying, Coexisting hydrates, $\mathrm{pH}$ of liquid phase, $\mathrm{Ca}^{2+}$ concentration of liquid phase 